\title{
Gene Regulatable Lentiviral Vector System
}

\author{
Yasutsugu Suzuki ${ }^{1,2}$ and Youichi Suzuki ${ }^{1}$ \\ ${ }^{1}$ Yong Loo Lin School of Medicine, National University of Singapore \\ ${ }^{2}$ Graduate School of Biostudies, Kyoto University \\ ${ }^{1}$ Singapore \\ ${ }^{2}$ Japan
}

\section{Introduction}

The basic principle of current gene therapy is to deliver genetic material to a population of cells in the body, thereby preventing a disease or improving the clinical status of a patient. One of key factors for successful gene therapy is the development of effective delivery. To date, a plethora of gene delivery systems, termed "vectors", have been developed, and these fall into two broad categories: nonviral and viral vectors. Basically, the nonviral vector systems involve delivery of naked DNA or RNA into target cells with the aid of physical or chemical mediators such as cationic lipids. In terms of their simplicity, producibility, and immunogenicity, nonviral vector systems hold advantages over viral vector systems. However, in terms of the efficiency of gene delivery and expression, the viral vector systems are considered as more ideal (Goverdhana et al., 2005; Verma \& Weitzman, 2005).

Although a variety of gene-transfer vectors based on RNA and DNA viruses have been adapted to deliver foreign genes to target cells in vitro and in vivo, most viral vectors are derived from adenoviruses and retroviruses. Adenoviruses are DNA viruses that are characterized by a nonenveloped icosahedral virion containing a double-stranded linear DNA genome of 30-36 kb (Berk, 2007). The virus enters the target cell by endocytosis via interactions between the fiber protein on the virion and the adenoviral receptor on the cell surface followed by the subsequent binding of a second virion protein, penton, to a cellular integrin protein. Inside the cell, uncoating of virions takes place in the cytoplasm where the viral DNA genome remains associated with a core-derived protein that promotes efficient nuclear entry of the viral genome. Within the nucleus, viral DNA exists as an episome, consequently replication of the viral genome takes place in the nucleus (Leopold et al., 1998). Adenovirus genes are mainly divided into two classes, early and late, based on the time of expressions during the replication. Many of the recombinant adenovirus vectors used in gene transfer have been generated by the deletion and/or mutation of the early genes which are mostly involved in the activation of other viral genes, replication of the viral DNA genome, modulation of host immune responses, and inhibition of host cell apoptosis (Armentano et al., 1995; Armentano et al., 1999; Bett et al., 1994; Brough et al., 1997; Danthinne\& Imperiale, 2000; Fallaux et al., 1996; Flint \& Shenk, 1997; Gao et al., 1996; Graham et al., 1977; Imler et al., 1996; Wang et al., 1995; Yeh et al., 1996). More recently, the helper-dependent adenoviral vectors, so-called "gutted" vectors, 
have been created by removing most of the viral genes from adenoviral genome (Kochanek et al., 1996; Lowenstein et al., 2002; Ng et al., 2001; Parks et al., 1996; Umana et al., 2001). Although the gutted vectors need to employ a helper virus that provides all the viral proteins necessary for vector production (Kochanek et al., 1996; Lowenstein et al., 2002; Ng et al., 2001; Parks et al., 1996; Umana et al., 2001), defect of all the viral-coding sequences theoretically allows the cloning of large DNA fragments up to $36 \mathrm{~kb}$ (Goverdhana et al., 2005). Although their tropism for the airway epithelial cells meant that adenovirus-based vectors were originally developed for the treatment of genetic lung diseases such as cystic fibrosis (Flotte et al., 2007), one of the major advantages of adenoviral vectors is that they are able to infect a wide variety of cells in a cell-cycle independent manner (Bergelson et al., 1997; Cullen, 2001; Tomko et al., 1997; Whittaker et al., 2000). However, one limitation is the persistence of transgene expression; adenoviral vector-mediated gene expression is short-term, ranging from two weeks to a few months. Thus, this vector is more appropriate for use in treatment of diseases that require high and transient gene expression (Robbins \& Ghivizzani, 1998).

In contrast with adenoviral vectors, retroviruses have a substantial advantage as vectors for the sustained expression of a transgene in target cells (Verma \& Weitzman, 2005). Retroviruses are enveloped RNA viruses belonging to the Retroviridae family. The retroviral particle contains two copies of linear, positive sense, single-stranded RNA of 7-13 kb in length. All members of the Retroviridae family harbors at the minimum three essential genes: gag for structural proteins, pol for enzymes, and env for envelope. In the retroviral genome, the gag gene is positioned upstream of the pol gene, and the Pol polyprotein is generated as a fusion protein with the Gag polyprotein (Gag-Pol). As we shall see in the next section, the viral RNA genome is converted into a double-stranded DNA copy by reverse transcriptase (RT), a processing product of Pol, soon after the entry into the target cell (reverse transcription). Subsequently, the viral DNA is transported to the nucleus and covalently joined with cellular chromatin. This joining step is called integration and it is catalyzed by integrase (IN), another processing product of Pol. The integration step as well as the reverse transcription is hallmark of retroviral infection. Once integrated, the viral DNA serves as a template for the transcription of viral genes, enabling sustained gene expression in infected cells. The integrated viral DNA also contains cis-acting sequences termed the long terminal repeat (LTR) at its termini, which consist of $3^{\prime}$ unique elements (U3), repeat elements (R), and $5^{\prime}$ unique elements (U5). The 5' LTR sequence functions as the promoter sequence for gene expression, in which viral RNA transcription is initiated at the U3-R, and the transcripts are polyadenylated at the R-U5 boundary of the 3' LTR. The development of retrovirus as a gene transfer vector was first achieved with oncoretroviruses in the 1980s (Mann et al., 1983; Miller \& Rosman, 1989; Shimotohno \& Temin, 1981; Tabin et al., 1982; Watanabe \& Temin, 1983; Wei et al., 1981); nowadays Moloney murine leukemia virus (MoMLV), one of the well characterized oncoretroviruses, is commonly used for therapeutic applications (Anderson et al., 1990; Blaese et al., 1993; Guild et al., 1988; Levine\& Friedmann, 1991; Miller, 1992a, b). However, the important limitation of the MoMLV-derived vector is its cell cycle dependency: this virus lacks the ability to infect non-dividing cells (Harel et al., 1981; Hatziioannou \& Goff, 2001; Lewis \& Emerman, 1994; Miller et al., 1990; Roe et al., 1993). Unlike the MoMLV, lentiviruses, a separate genus of the Retroviridae family including human immunodeficiency virus type-1 (HIV-1), can infect both dividing and non-dividing cells (Bukrinsky et al., 1992; Hatziioannou \& Goff, 2001; Lewis et al., 1992; Lewis \& 
Emerman, 1994). The ability to infect non-dividing cells is not restricted to in vitro cell culture as lentivirus-derived vectors are capable of transducing certain quiescent or terminally differentiated cells such as macrophages and microglia (Miyake et al., 1998; Naldini et al., 1996; Weinberg et al., 1991). This property makes the lentivirus an attractive choice for gene transfer vector (Suzuki \& Craigie, 2007).

It is well known that HIV-1 is the causative agent for acquired immunodeficiency syndrome (AIDS). Currently, the standard AIDS treatment, termed highly active antiretroviral therapy (HAART), is to use cocktail of antiretroviral drugs that targets different HIV-1 enzymes including reverse transcriptase and protease. However, although it successfully causes suppression of HIV-1 RNA detected in plasma for a prolonged period of time and dramatic decrease of patient mortality (Palella et al., 1998; Volberding \& Deeks, 2010), this pharmacological therapy is facing problems such as drug resistance and side effects in administrated individuals (Meadows \& Gervay-Hague, 2006; Richman, 2001). Hence, viral vector-based gene therapy should offer a new approach to supplement the need for current drug regimens for the treatment of HIV/AIDS (Poluri et al., 2003; Strayer et al., 2005). Genetic modification of HIV-susceptible cells or hematopoietic stem cells (HSCs) by expressing anti-HIV transgenes should be one of the goals of the HIV gene therapy (Kitchen et al., 2011). In this regard, the lentiviral vector has the potential advantage for transduction because of its ability to infect quiescent cells including HSC (Miyoshi et al., 1999). However, incorporation of anti-HIV genes into an HIV-based lentiviral vector can create problems for production of the vector itself; expression of the anti-HIV trans gene in the producer cells can interfere with vector production (Banerjea et al., 2003; Li et al., 2003; Mautino \& Morgan, 2002c). One way to avoid this difficulty is to introduce a gene regulatable system in which the target transgene is kept silent during vector production and expression is subsequently induced on following infection of the vector in target cells.

Several regulatable gene expression systems have been developed and applied to viral vectors including lentiviral vectors (Goverdhana et al., 2005; Weber \& Fussenegger, 2004). In this chapter, we focus on recent development of the gene-regulatable lentiviral vectors and discuss the suitability of the vectors for anti-HIV therapy.

\section{Biology of HIV-1 replication}

\subsection{Genomic organization and gene expression}

Lentiviruses, as represented by HIV-1, are also called complex retroviruses, which are characterized by a set of additional regulatory and accessory genes encoded in the viral genome (Cullen, 1991; Frankel \& Young, 1998). In the case of HIV-1, the DNA genome converted from the RNA genome is about $9.7 \mathrm{~kb}$ and contains nine ORFs; in addition to the gag, pol, and env genes that are typical of all retroviruses, there are two regulatory (tat and rev) and four accessory (vif, vpr, vpu, and nef) genes (Fig. 1). These protein-coding regions are flanked by $5^{\prime}$ and $3^{\prime}$ LTR that are required for reverse transcription, integration, and gene expression steps.

The complexity of HIV-1 is also characterized by its specific pattern of viral gene regulation (Kingsman \& Kingsman, 1996). The HIV-1 LTR harbors several cis-acting sequences required for the initiation of viral RNA expression. The U3 region of the LTR is composed of a series of control elements that recruit a variety of transcription factors (Brady \& Kashanchi, 2005), and consequently, transcription of viral RNA initiates at the U3-R junction. However, the transcription activity of the U3 is basically low, and trans-acting proteins are required to 
enhance the viral RNA synthesis from the $5^{\prime}$ LTR. Viral regulatory protein, Tat is one of these transactivators (Brady \& Kashanchi, 2005). Tat interacts not with DNA, but with an RNA bulge of a stem-loop structure formed at the $5^{\prime}$ end of nascent transcripts, which is known as the transactivation response region (TAR) (Berkhout et al., 1989; Feng \& Holland, 1988). Binding of Tat to the TAR then recruits an active transcription elongation complex consisting of cyclin T1 (CycT1), CDK9, and some other factors (Brady \& Kashanchi, 2005). Subsequently, CDK9 leads the hyperphosphorylation of the C-terminal domain of RNA polymerase II, in turn resulting in a dramatic stimulation of transcriptional processivity (Brady \& Kashanchi, 2005).

More than 30 species of RNA are transcribed from the integrated HIV-1 DNA; these fall into three size classes of mRNA based on the pattern of splicing: unspliced, partially spliced, and multiply spliced RNAs. (Kingsman \& Kingsman, 1996; Purcell \& Martin, 1993; Schwartz et al., 1990). The unspliced transcript is full-length RNA (about $9 \mathrm{~kb}$ ) that is packaged as the viral genome into new viral particles but it also functions as mRNA to produce Gag and Gag-Pol polyproteins. The partially spliced transcripts (about $4 \mathrm{~kb}$ ) encode Vif, Vpr, Vpu, and Env proteins. At early times after infection, however, the multiply spliced RNAs are predominant, and their encoded proteins, Tat, Rev, and Nef are highly produced (Kim et al., 1989).

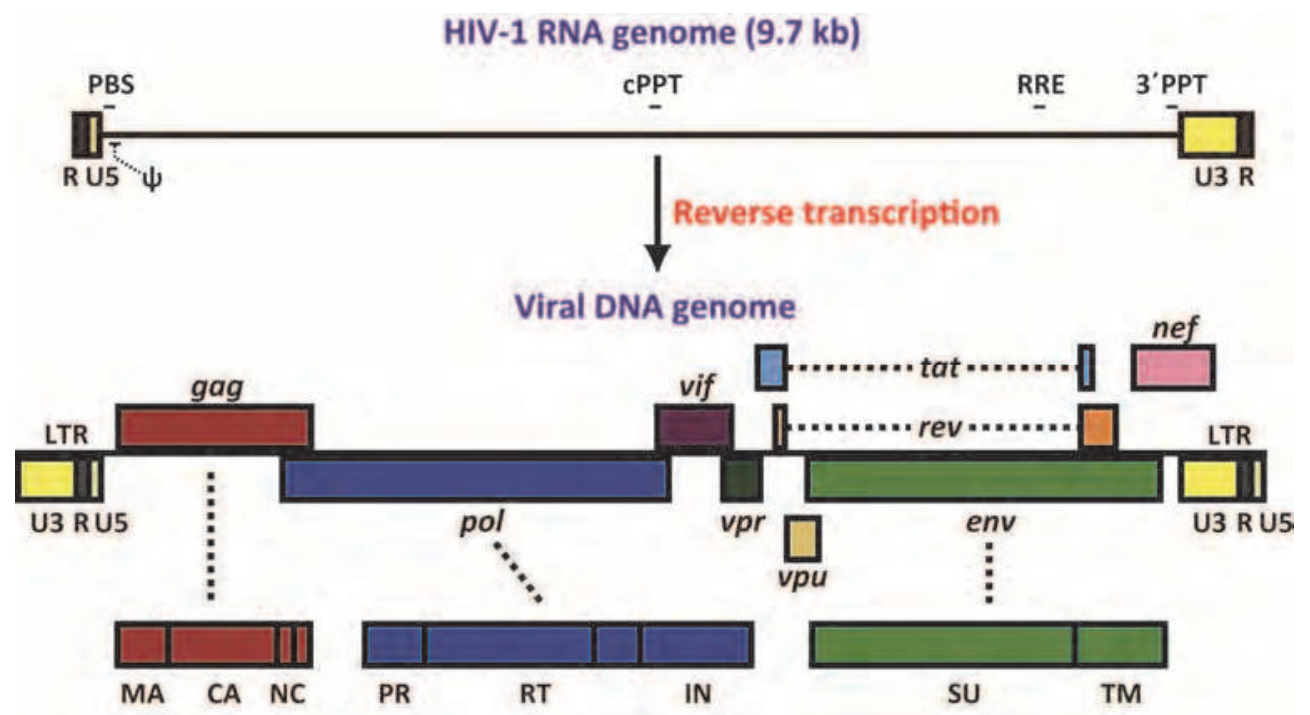

Fig. 1. Organization of the HIV-1 genome.

\subsection{Replication cycle}

HIV-1 infection begins with the binding of the viral envelope (Env) glycoprotein gp120 (surface envelope protein: SU) to the CD4 receptor molecule on the surface of host cells. Consequently, the main target cells for HIV-1 infection are the CD4+ subset of helper T cells and monocyte/macrophage lineages (Dalgleish et al., 1984; Landau et al., 1988; Stevenson, 2003). The gp120-CD4 interaction triggers a conformational change in the gp120 that facilitates subsequent binding to a secondary cellular receptor (coreceptor). While most HIV1 strains use either the $\alpha$-chemokine receptor CXCR4 or the $\beta$-chemokine receptor CCR5 as 
the coreceptor, other chemokine receptors or related proteins have been reported to serve as coreceptors for HIV-1 infection (Berger et al., 1999). This coreceptor usage is the basis for the differential cell-type tropism of HIV-1 strains. Formation of the gp120-CD4-coreceptor complex then induces refolding of the gp41 subunit of the Env (transmembrane envelope protein: TM), which allows the membrane fusion process between the virus and target cell (Melikyan, 2008).

After penetrating the cell membrane, the viral nucleoprotein core, which contains genomic RNA, is released into the cytoplasm, followed by the uncoating of the viral core that is required for the formation of the reverse transcription complex (RTC) (Arhel, 2010; Bukrinskaya et al., 1998; Fassati \& Goff, 2001). Reverse transcription, one of the defining steps of retrovirus infection, takes place in the RTC and it is initiated from the $3^{\prime}$ end of the tRNALys3 that is annealed to the primer binding site (PBS) near the $5^{\prime}$ end of the viral RNA genome. During the reverse transcription reaction, RT firstly synthesizes the minus-strand DNA along with the concomitant degradation of the RNA template by its RNase $\mathrm{H}$ activity (Basu et al., 2008). Subsequent synthesis of plus-strand DNA involves priming from two polyprine tracts (PPT), short RNA segments resistant to RNase $\mathrm{H}$ digestion, at the $3^{\prime}$ terminus ( $3^{\prime}$ PPT) and the center (central PPT: cPPT) of the HIV-1 genome. Once the $3^{\prime}$ end of the plus-strand DNA reaches the $5^{\prime}$ end of the cPPT, DNA synthesis proceeds by displacing the existing DNA fragments and stops at a central termination sequence (CTS) in the minus-strand DNA, resulting in a 99 bp triple-strand DNA structure in the center of the HIV-1 DNA (Arhel, 2010; Charneau et al., 1992; Charneau et al., 1994).

The newly synthesized full-length viral DNA remains associated with viral and cellular proteins in a large nucleoprotein complex called the preintegration complex (PIC) (Engelman, 2003). The HIV-1 PIC has been shown to contain RT, IN, matrix (MA), nucleocapsid (NC), and Vpr proteins (Lewinski \& Bushman, 2005; Suzuki \& Craigie, 2007). In addition to viral proteins, several cellular proteins have been reported as components of the HIV PIC (Suzuki \& Craigie, 2007). As mentioned above, unlike many oncoretroviruses, HIV-1 is able to infect non-dividing cells. Thus, the HIV-1 PIC is believed to carry karyophilic signals that direct transport across an intact nuclear membrane in non-dividing cells. Although the molecular mechanisms underlying the active transport of HIV-1 PIC into the nucleus is still poorly understood, several viral and cellular factors have been shown to be implicated in the nuclear import of the HIV-1 PIC (Fassati, 2006; Suzuki \& Craigie, 2007; Yamashita \& Emerman, 2006). Cell cycle-independent infection of HIV-1 is particularly important in the pathogenesis of the virus and the development of HIV-1-based lentiviral vectors (Blankson et al., 2002; Kaul et al., 2001; Somia \& Verma, 2000).

Following nuclear transport of the PIC, integration of viral DNA into the host chromatin takes place. IN is a key component of the PIC that catalyzes the integration. This reaction proceeds via three coordinated steps: $3^{\prime}$ end processing of the viral DNA, joining to the target DNA, and repairing of the gaps between viral DNA and target DNA. IN is responsible for the $3^{\prime}$ end processing and DNA joining steps, but the gap repair step is likely to be carried out by yet-to-be-identified cellular enzymes (Engelman, 2003) (Fig. 2).

The integrated DNA, called the provirus, is acted upon by cellular transcription factors to express viral genes. Early populations of the transcripts are the multiply spliced class of mRNA that encodes Tat, Rev, and Nef proteins (Kingsman \& Kingsman, 1996). Tat enhances production of viral mRNAs by more than two log via interaction with TAR and a cellular elongation complex (Brady \& Kashanchi, 2005). There is then an increase in the partially spiced and unspliced mRNAs along with a concomitant decrease in the multiply spliced 
mRNAs, which is caused by the accumulation of Rev protein. Rev is also required for the nuclear export of partially spliced and unspliced mRNAs. These classes of viral RNAs contain a highly structured cis-acting element termed Rev response element (RRE) that is located in the env coding region. Rev bears a leucine-rich nuclear export signal (NES) and, via association with the RRE, mediates nuclear-to-cytoplasmic transport of the partially spliced and unspliced RNAs, resulting in production of Gag, Gag-Pol, Env, and accessory proteins (Pollard \& Malim, 1998).

Following the synthesis of the full-length viral RNA genome and the viral proteins, these components are assembled together to produce new viruses. In HIV-1, the assembly process takes place at the plasma membrane (Ono, 2010). Gag protein plays a central role in the formation of virions; this protein is synthesized as a $55 \mathrm{kDa}$ precursor protein for matrix (MA), capsid (CA)), and nucleocapsid (NC) proteins. The Gag precursor proteins are rapidly targeted to the plasma membrane where they multimerize. Although the multimerization of the Gag is sufficient to give rise to virus like particles, incorporation of Gag-Pol proteins is integral to the formation of infectious virions (Wu et al., 1997). Gag-Pol is a $160 \mathrm{kDa}$ multidomain protein consisting of RT, IN, and protease (PR), and it too relocates to the plasma membrane, where Gag and Gag-Pol are assembled into virus particles. In the HIV-1 genome, Gag and Pol are encoded by overlapping ORF; Gag-Pol is generated by a ribosomal frameshifting during translation of the gag gene. This translation mechanism limits intracellular synthesis of Gag-Pol at 10- to 20-fold-lower than Gag (Haraguchi et al., 2010). Env glycoprotein, which is synthesized in the rough endoplasmic reticulum (ER), reaches the cell surface and is incorporated into virus particles. The MA domain of Gag has been suggested to be important for the recruitment of Env into virions (Ono, 2010). Encapsidation of the viral genomic RNA is directed by an interaction between the NC domain of Gag and the packaging signal (or $\psi$-site located in the $5^{\prime}$ region of the gag initiation codon. The $\psi$ sequence also acts as a dimerization signal for the viral RNA genome. Eventually, the virus particle is pinched off the host cell membrane (budding). Recent evidence has revealed that a number of cellular proteins in the vacuolar protein sorting (VPS) pathway are involved in the HIV-1 budding process. After release from the plasma membrane, virus particles undergo a maturation step, in which Gag and Gag-Pol precursor proteins are cleaved by the viral PR to yield the functional mature proteins of infectious HIV-1 (Vogt, 1996) (Fig. 2).

Accessory proteins (i.e. Vif, $\mathrm{Vpr}, \mathrm{Vpu}$, and Nef) are dispensable for viral replication in many in vitro cell culture systems, but these proteins are likely to be required for efficient replication and pathogenicity of HIV-1 in vivo (Malim \& Emerman, 2008).

\section{Development of HIV-1-derived lentiviral vectors}

Although retrovirus vectors derived from oncoretroviruses were introduced first, in recent years, attention of the viral vector research has been focused on lentiviruses such as HIV-1 and equine infectious anemia virus (EIAV) due to their ability to infect non-dividing cells. In particular, HIV-1 should be one of the most practical gene transfer vectors for gene therapy applications because this is the best studied retrovirus. However, HIV-1 is a human pathogen that causes destruction the of $\mathrm{CD}^{+}$helper T lymphocytes and the subsequent loss of immune competence (Forsman \& Weiss, 2008). Therefore, considerable efforts have been devoted to develop efficient HIV-1-derived lentiviral vectors with improved biosafety features.

So far, three different generations of HIV-1-based lentiviral vectors have been established, which is based on the level of safety improvements in viral vector production (Fig. 3). 


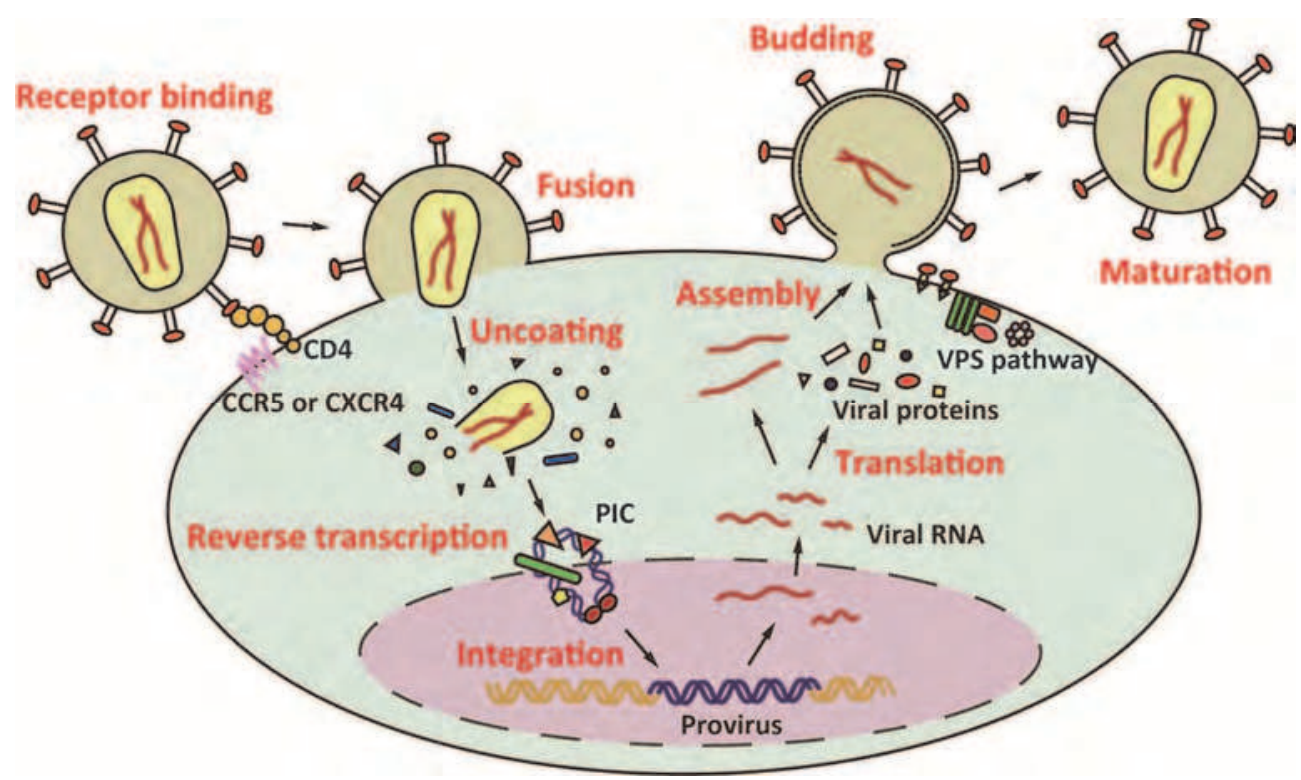

Fig. 2. Schematic representation of HIV-1 replication. HIV-1 enters target cells by first binding to the CD4 receptor and a coreceptor (CCR5 or CXCR4), this allows fusion between the cellular and viral membranes. After entry, the viral nucleoprotein core containing the genomic RNA is released into cytoplasm. Reverse transcription takes place in a nucleoprotein complex termed the RTC. The synthesis of full-length viral DNA produces an integration-competent nucleoprotein complex called the PIC and this nucleoprotein complex mediates integration of viral DNA into chromatin. Integrated viral DNA, called the provirus, serves as a transcription template for the synthesis of viral mRNA and genomic RNA. Following the synthesis of viral proteins, the viral components are assembled together to produce new virions, the virus particles then undergo a maturation step to generate infectious HIV-1.

\subsection{First-generation lentiviral vectors}

One of the key safety concerns in the use of HIV-derived vectors is the generation of replication competent lentiviruses (RCL). Earlier development of lentiviral vectors was achieved by transient transfection of human embryonic kidney (HEK293T) cells with three separate plasmid DNAs encoding i) the lentiviral vector genome which was composed of the wild-type 5' and 3' LTR, a part of the gag gene corresponding to the $\psi$ sequence, a part of the env gene containing the RRE, an internal promoter, and the desired gene (transfer vector plasmid), ii) the HIV-1 genome containing all viral genes with the exception of the env gene (packaging plasmid), and iii) the vesicular stomatitis virus G protein (VSV-G) that improves the stability and broadens the cellular tropism of lentiviral vectors (Burns et al., 1993; Naldini et al., 1996). However, in this vector production system, there is a potential risk for the generation of RCL; a recombination event would occur during subsequent reverse transcription in transduced cells between two RNAs that are derived from the transfer vector plasmid and the packaging plasmid and incidentally copackaged within the same virion (Fig. 3A). 
A

i) Transfer vector plasmid

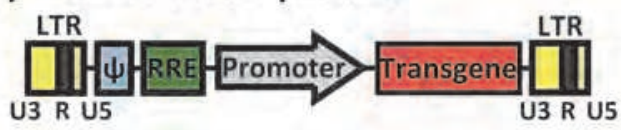

iii) Envelope expressingplasmid

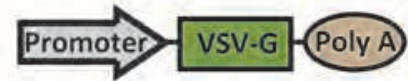

ii) Packaging plasmid

B

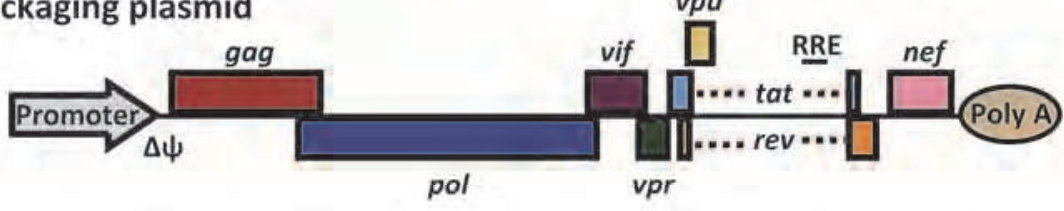

i) Transfer vector plasmid



iii) Envelope expressingplasmid

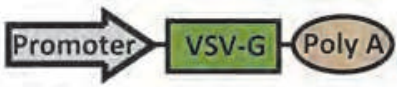

\section{ii) Packaging plasmid}

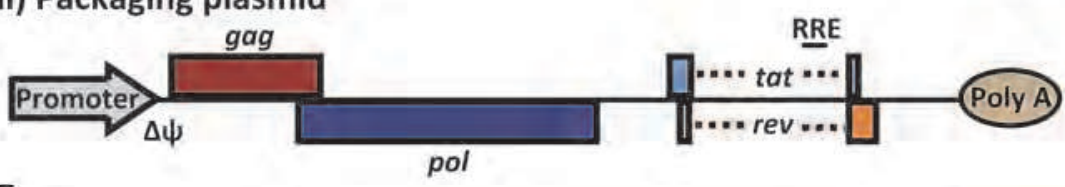

C

i) Transfer vector plasmid

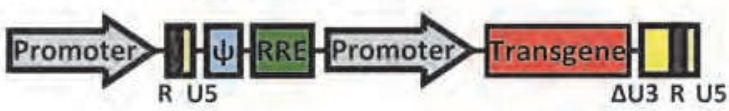

ii) Packaging plasmid

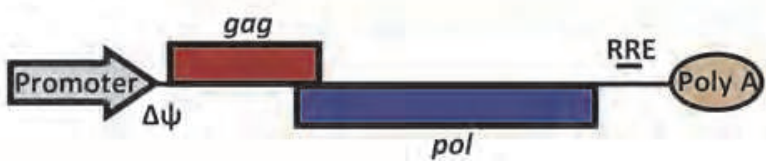

iii) Envelope expressingplasmid

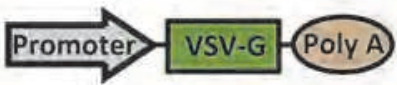

iv) Rev expressing plasmid

Fig. 3. Schematic representation of HIV-1-derived lentiviral vector packaging constructs. The first-generation lentiviral vectors (A) are produced by three separate plasmid DNAs encoding the vector genome, all HIV-1 genes except for env gene, and Env protein (VSV-G). To reduce the potential risk of the generation of replication competent viruses, all accessory genes (vif, vpr, vpu, and nef) are removed from (or mutated in) the packaging plasmids in second-generation lentiviral vectors (B). In third-generation lentiviral vectors, the enhancer/promoter unit is deleted from the U3 region of the $3^{\prime}$ LTR $(\Delta \mathrm{U} 3)$ in transfer vector plasmids (SIN vector). Additionally the U3 region of the 5' LTR is replaced with the CMV promoter, enabling Tat-independent production of the lentiviral vectors (C). LTR, long terminal repeat; $\psi$, packaging signal; RRE, Rev response element. 


\subsection{Second-generation lentiviral vectors}

The second-generation lentiviral vectors basically employ a similar three-plasmid system as the first generation vectors. Yet, in order to overcome the safety issue attributable to the first-generation vectors, the second-generation lentiviral vectors were generated without production of all accessory proteins (Vif, $\mathrm{Vpr}, \mathrm{Vpu}$, and $\mathrm{Nef}$ ) via mutation or deletion of these genes from the packaging plasmid (Gasmi et al., 1999; Kim et al., 1998; Zufferey et al., 1997) (Fig. 3B).

\subsection{Third-generation lentiviral vectors}

The second-generation vectors, however, still carry the transcriptionally active LTR elements that could induce the homologous recombination between the vector genome and wild-type HIV-1. This would be particularly problematic if the lentiviral vectors are used for gene therapy of HIV/AIDS. Thus, further improvements were made in the third-generation lentiviral vectors. To minimize the transcriptional activity of the LTR in transduced cells, the enhancer/promoter unit was deleted from the U3 region of the 3' LTR in transfer vector plasmids. During reverse transcription in the transduced cells, this deletion is transferred to the $5^{\prime}$ LTR of the lentiviral DNA, thereby reducing promoter activity of the integrated provirus (self-inactivating [SIN] vector) (Miyoshi et al., 1998; Zufferey et al., 1998). Additionally, the U3'region of the 5' LTR in the transfer vector plasmid was replaced with the cytomegalovirus (CMV) promoter, which enabled Tat-independent transcription of the lentiviral vector genome in producer cells (Dull et al., 1998; Miyoshi et al., 1998). In these SIN vectors, there is no compete HIV-1 U3 sequence. Moreover, expression of Rev protein is directed by a separate plasmid, but not by the packaging plasmid encoding gag and pol genes (Wagner et al., 2000) (Fig. 3C). Currently, third-generation SIN lentiviral vector system offers the best safety profile in terms of generation of RCL because this vector requires only three HIV-1 genes (gag, pol, and rev) for production, however safety improvement in the design of HIV-1-derived lentiviral vectors is still one of the challenging areas in gene therapy study

\section{Incorporation of regulatable gene expression systems in HIV-1-derived lentiviral vectors}

Lentiviral vectors hold great promise for a gene therapy approach to inherited and acquired diseases. In these particular clinical settings, it would be more beneficial to reversibly control transgene expression in a dose and time dependent manner as illustrated in the field of angiogenesis and Parkinson's disease (Ma et al., 2002; Yancopoulos et al., 2000). To meet the standards required for clinical applications, a number of regulatable gene expression systems have been developed, and some of them are indeed incorporated into viral vectors including HIV-1-derived lentiviral vectors (reviewed in Goverdhana et al., 2005).

Although early development of the regulatable gene expression systems was based on naturally occurring inducible cellular promoters that respond to exogenous signals, these types of systems had limitations due to the pleiotropic effects of the inducer, high levels of "leaky" background expression and poor performance in inducibility. Therefore, recent efforts have been mostly focused on the development of chimeric gene regulatable systems derived from prokaryotic, eukaryotic, and viral elements, which are designed to enhance specificity and activity of transgene expression (Fussenegger, 2001). 


\subsection{Tetracycline-regulated system}

The most widely used inducible system in lentiviral vectors is the tetracycline (Tet)regulated system. This system was originally based on binding of the Tet-controlled repressor (tetR), a $23.6 \mathrm{kDa}$ protein of Escherichia coli (E. coli), to the operator sequence of $E$. coli Tet resistance gene (Baron \& Bujard, 2000), but further developed to be operated in mammalian cells by the generation of a chimeric protein in which tetR is fused with herpes simplex virus (HSV) VP16 protein, a eukaryotic transactivator (Tet-controlled transactivator: tTA) (Gossen \& Bujard, 1992). In the absence of Tet or its derivatives such as doxycycline (Dox), the tTA binds the Tet-response element (TRE) that is composed of seven tandem copies of Tet operator (tetO) sequences and placed upstream of the CMV minimal promoter (Baron \& Bujard, 2000). This type of original Tet-regulated system, called Tet-off system, has been incorporated into HIV-1-derived lentiviral vectors (Gascon et al., 2008; Haack et al., 2004; Kafri et al., 2000; Vigna et al., 2002) (Fig. 4A). In the first study that employed the Tetoff system in the context of a lentiviral vector, transgene induction by the withdrawal of Dox resulted in a more than 500-fold increase in the expression level of a GFP reporter gene (Kafri et al., 2000). Of note, the Dox-dependent regulation of GFP expression was also confirmed in the brain cells of rats that had been transduced by the lentiviral vector and then administered Dox through drinking water, indicating applicability of the gene regulatable lentiviral vectors in vivo (Kafri et al., 2000). However, even in the presence of Dox, high levels of basal GFP expression was observed, which would be attributed to the transcriptional interference arising from the neighboring CMV promoter or the wild-type HIV-1 LTR.

In addition to the background activity in the repressed state, the major limitation of the Tetoff system is the requirement of continuous administration of Tet or Dox to suppress transgene expression. To overcome this limitation, another type of Tet-controlled gene expression system was established by introduction of several permutations in the tTA protein of the Tet-off system. The mutant tTA binds the tetO sequences only in the presence of Tet/Dox: it exhibits opposite function (Gossen et al., 1995). Because this modified version of regulatable system, the so-called Tet-on system, shows rapid kinetics of gene upregulation compared to Tet-off system, several HIV-1-derived lentiviral vectors have been constructed using the Tet-on system as well (Johansen et al., 2002; Koponen et al., 2003; Pluta et al., 2005; Reiser et al., 2000; Vogel et al., 2004) (Fig. 4B).

One more approach to permit tight control of transgenes in the context of a lentiviral vector is demonstrated in the Tet-regulated system that employs a chimeric tetR fused with the Krüppel-associated box (KRAB) domain, a transcriptional regulator found in many DNA binding zinc-finger proteins (Szulc et al., 2006; Wiznerowicz \& Trono, 2003). Binding of the $\mathrm{KRAB}$ domain-containing repressor protein to DNA recruits various heterochromatininducing factors, thereby suppressing activity of cellular RNA polymerases (RNAPs) II and III. This transcriptional silencing can be exerted no farther than 2-3 kb away from the repressor binding site. In the new design of Tet-regulated lentiviral vector system, the tetO site was inserted upstream of the RNAP III promoter-driven small hairpin RNA (shRNA) expression cassette which was located in the U3 region of lentiviral vector genome, and the activity of tetO-linked shRNA expression unit was tightly suppressed in the presence of KRAB-fused tTA and in the absence of Dox. The KRAB-fused tTA/Dox-dependent inhibition of transcriptional activity was also observed in the internal RNAP II promoter for a reporter transgene within the same vector genome. However, when the transduced cells were treated with Dox, shRNA was produced to achieve RNA interference, which was 
correlated with the expression of the reporter transgene (Szulc et al., 2006; Wiznerowicz \& Trono, 2003).

One drawback of the Tet-regulated system is that there is a requirement to deliver two distinct expression units into a target cell: one is for transactivator (e.g. tTA) expression and the other is for transgene expression. In a binary lentiviral vector approach in which tTA and transgene expression cassettes are cloned into separate vectors, a population cells that is singly transduced with either tTA or transgene would be produced, resulting in low inducibility as a whole. This can be a bottleneck, particularly in relevant applications of the Tet-regulated lentiviral vector systems in clinical use. Single vector systems that contain the entire regulatable component in a unique vector is one of the solutions to guarantee simultaneous expression of the two expression units in the target gene, and these have indeed been established (Gascon et al., 2008; Kafri et al., 2000; Szulc et al., 2006; Vogel et al., 2004).

\subsection{Mifepristone-inducible system}

This gene regulatable system (also called GeneSwitch system) is based on a mutated human progesterone receptor that responds to the synthetic progestin antagonist but fails to bind natural progestins or other steroids (Burcin et al., 1999; Wang et al., 1994). Similar to Tetregulated system, this system requires two components: the regulator (transactivator) protein and the inducible promoter sequence that drives transgene expression. The regulator is a hybrid protein consisting of a GAL4 DNA-binding domain from Saccharomyces cerevisiae, a ligand-binding domain of mutant progesterone receptor, and an activation domain of the p65 subunit of human NF- $\mathrm{KB}$ (Burcin et al., 1999). The inducible transgene expression unit contains six copies of the GAL4 upstream activating sequences (UAS) and the TATA box sequence in its promoter (Abruzzese et al., 1999). The progestin antagonist commonly used as an inducer for the GeneSwitch system is mifepristone (MFP, RU486). The regulator protein initially exists as an inactive monomeric form. However, in the presence of MFP, it binds to the MFP and undergoes a conformational change, causing the regulator protein to become an active homodimer. The active form of the regulator is able to bind to GAL4 UAS and induce transgene expression (Nordstrom, 2003) (Fig. 4C).

Sirin and Park have incorporated the MFP-inducible gene expression system into HIV-1derived lentiviral vectors (Sirin \& Park, 2003). In their design, two different SIN lentiviral vectors were constructed, in which either the regulator protein expression unit or the inducible transgene expression unit was cloned. When human cell lines (HeLa and Huh7 cells) were infected with both lentiviral vectors, up to a 275 -fold increase in the number of reporter fluorescent protein-positive cells was observed at 48 hours following MFP treatment. Similar effective induction was also detected in cells transduced by a lentiviral vector expressing the human $\alpha_{1}$-antitrypsin (hAAT) with an extremely low level of basal hAAT expression (Sirin \& Park, 2003).

Although an in vitro study using adenovirus vector expressing the chloramphenicol acetyl transferase (CAT) as a reporter transgene gene demonstrates that induction level of the GeneSwitch system is lower than that of the Tet-regulated (Tet-on) system (Molin et al., 1998), the GeneSwitch system holds some advantages in its application to human gene therapy. The majority of components of the regulator protein are derived from human proteins, which has less impact on cell viability and immunogenicity. In addition, MFP has been approved by the Food and Drug Administration (FDA) for use in humans (Ulmann et al., 1995), and the concentration of MFP need for transgene induction is significantly lower than the concentration for its anti-progesterone effect (Nordstrom, 2003). 
A

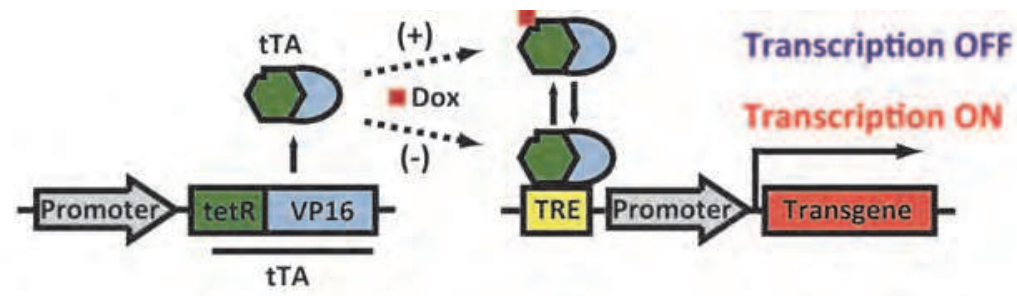

B



C

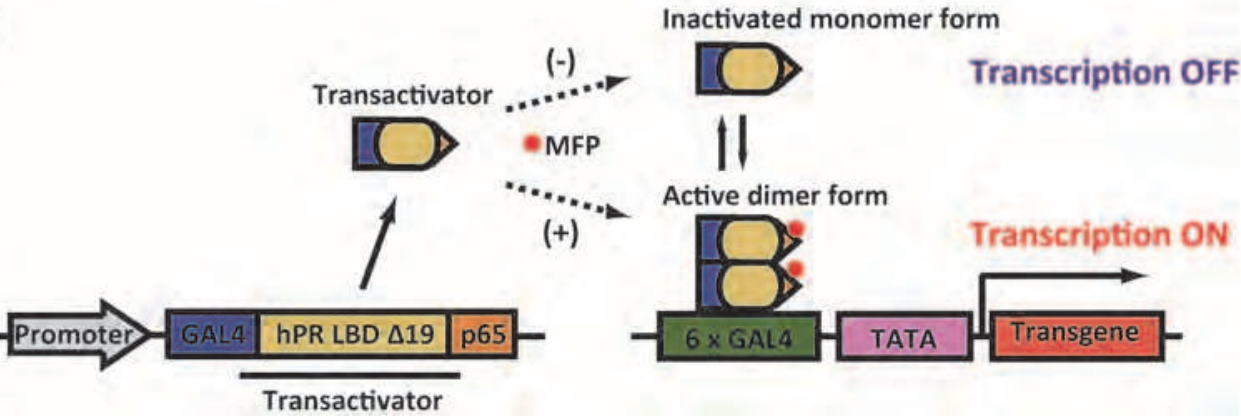

Fig. 4. Diagrams of two regulatable gene expression systems. The Tetracycline-regulated system is the most widely used inducible system in lentiviral vectors. In a Tet-off system (A), the Tet-controlled transactivator (tTA), a chimeric protein of E. Coli Tet-controlled repressor (tetR) and HSV VP16, binds the Tet-response element (TRE) upstream of the CMV promoter in the absence of Tet or Dox. On the other hand, in the Tet-on system (B), several mutations are introduced into the tTA (rtTA) so that this transactivator binds the TRE in the presence of Dox. The Mifepristone-inducible system (GeneSwitch) has been also incorporated into HIV-1-derived lentiviral vectors. In this system, the transactivator is a chimeric protein that comprises the GAL4 DNA-binding domain from Saccharomyces cerevisiae fused to the ligand-binding domain of a mutant progesterone receptor (hPR LBD $\Delta 19)$ and the activation domain of the p65 subunit of human NF- $k B$. In the presence of mifepristone (MFP), the chimeric transactivator binds to the six copies of GAL4 upstream of the activating sequences and induce transgene expression (C). TATA, TATA box sequence.

\subsection{Ecdysone-regulated system}

The Drosophila melanogaster ecdysone receptor (EcR)-based gene regulatable system has been adapted to lentiviral vectors (Galimi et al., 2005). EcR is a member of the nuclear receptor superfamily that mediates a cascade of morphological changes in Drosophila, triggered by the steroid hormone ecdysone. Ecdysone regulates gene expressions by interacting with the functional EcR, which in turn induces binding of the EcR to DNA regulatory elements 
EcREs) near target genes (No et al., 1996). The ecdysone-regulated gene expression system incorporated into lentiviral vectors employed two elements: i) the dimeric regulator protein of the EcR fused with HSV VP16 activation domain (VgEcR) and the retinoid X receptor (RXR), and ii) the hybrid promoter between the glucocorticoid response element and that of type II nuclear receptors (E/GRE) (Galimi et al., 2005). Upon exposure to ecdysone or synthetic analogues such as ponasterone $\mathrm{A}$, the $\mathrm{VgECR} / \mathrm{RXR}$ heterodimer binds to the E/GRE, resulting in induction of transgene expression (Saez et al., 2000). One advantage of the ecdysone-regulated gene expression system is the pharmacological profile of the inducer that allows for fast distribution and clearance after administration in vivo (Saez et al., 2000). Additionally, the inducible promoter is not responsive to natural nuclear receptors (No et al., 1996).

In the single vector approach, the inducible GFP expression cassette containing E/GRE as well as a CNV promoter-driven bicistronic unit for VgEcR and RXR expressions were cloned into an HIV-1-derived SIN lentiviral vector. However, this ecdysone-regulated system was also applicable to the binary vector system, in which the $\mathrm{VgEcR} / \mathrm{RXR}$ expression unit was in one lentiviral vector and the inducible transgene expression unit was in the second vector. The latter approach would be of value in deliver of longer transgene. These lentiviral vectors have been shown to successfully deliver the ponA-inducible GFP expression units in vitro and ex vivo (Galimi et al., 2005).

\subsection{Other regulatable systems}

Besides the Tet- MFP-, and ecdysone-regulated systems, different types of inducible lentiviral vectors have been generated based on the other chimeric regulatable systems, which include streptogramin-adjustable expression system derived from Streptomyces coelicolor (Mitta et al., 2004) and gaseous acetaldehyde-inducible expression system derived from Aspergillus nidulans (Hartenbach \& Fussenegger, 2005). Although some endogenous cellular elements that respond to exogenous signals or stress have been adapted to HIV-1and EIAV-derived lentiviral vectors (Beutelspacher et al., 2005; Hurttila et al., 2008; Parker et al., 2009), the pleiotropic effects exerted by the inducing agent would be a drawback in a human therapeutic context (Fussenegger, 2001).

\section{Application of a gene regulatable lentiviral vector for HIV-1 inhibition}

Lentiviral vector-mediated gene therapy has the potential to improve the clinical state of a patient with HIV-1. This goal would be accomplished by ex vivo transduction of anti-HIV genes into $\mathrm{CD}^{+}$virus target cells such as helper $\mathrm{T}$ cells and macrophages or $\mathrm{CD} 34^{+}$ progenitor cells (HSCs), making them resistant to HIV-1 infection (intracellular immunization approach) (Baltimore, 1988; Kitchen et al., 2011). So far, various studies have reported the delivery of anti-HIV genes by HIV-1-based lentiviral vectors in vitro and in vivo, and the anti-HIV genes can be categorized as either RNA- or protein-based (Mukhtar et al., 2000) (Banerjea et al., 2003; Dropulic et al., 1996; Klimatcheva et al., 2001; Li et al., 2003; Mautino et al., 2001; Mautino \& Morgan, 2002a, b, c). Among the RNA-based anti-HIV genes include a ribozyme that cleaves the U5 region of HIV-1 RNA by its enzymatic activity (Dropulic et al., 1996), an antisense RNA that hybridizes the transcripts of HIV-1 env gene to inhibit translation of Env (Mautino \& Morgan, 2002a, c), and small interfering RNA (siRNA) that induces sequence-specific degradation of HIV-1 RNA (Banerjea et al., 2003). In the protein-based approach, the transdominant negative mutant of Rev (TdRev) is best 
described as an anti-HIV gene used in the setting of lentiviral vectors (Klimatcheva et al., 2001; Mautino et al., 2001; Mautino \& Morgan, 2002c; Mukhtar et al., 2000). The TdReV named RevM10 is a derivative of HIV-1 Rev in which two amino acid mutations are introduced in the C-terminus activation domain, and hampers nuclear export of HIV-1 mRNAs via the formation of inactive multimers with WT Rev (Hope et al., 1992; Malim et al., 1989). It should be noted that RevM10 has been already tested in phase I clinical trials to treat HIV infection via transduction of the gene into CD34+ cells with MoMLV-derived retroviral vectors (Kang et al., 2002; Kitchen et al., 2011; Podsakoff et al., 2005).

Although a promising approach for HIV gene therapy, constitutive expression of anti-HIV genes in the context of HIV-1-derived lentiviral vectors could encounter a problem of selfinhibition of the vector particle production, resulting in significant decrease of viral infectious titer (Mautino \& Morgan, 2002b). This problem of self-inhibition can be solved by several means. If the anti-HIV gene targets specific sequences in the HIV-1 RNA, one strategy to avoid the self-inhibition would be to engineer nucleotide sequences of lentiviral vector genome and packaging genes in order that anti-HIV gene will exclusively recognize wild-type virus in transduced cells. As for TdRev, the inhibition of vector production could be overcome by replacement of the HIV-1 Rev-dependent nuclear export element (e.g. RRE) with the one derived from another lentiviruses, conferring Rev-independent property on the lentiviral vectors (Mautino et al., 2001; Taylor et al., 2008). But, if the anti-HIV genes are designed to target HIV-1 at more fundamental process such as virion formation and budding processes, an ideal strategy would be the incorporation of regulatable transgene expression system into lentiviral vectors, in which expression of the anti-HIV gene is "OFF" during vector production and turned "ON" in the target cells.

In order to assess the availability of gene regulatable systems in inhibition of HIV-1, we have generated HIV-1-derived lentiviral vectors harboring the MFP-inducible transgene expression unit (Shinoda et al., 2009). In the study, two SIN lentiviral vectors were designed to incorporate the MFP-inducible unit in either the forward or the reverse orientation with respect to the direction of transfer vector genome (designated as forward and reverse vectors, respectively), since it has been reported that promoter activity of the internal gene expression unit could be affected by its orientation and/or the presence of adjacent LTR (Chen et al., 1992; Reiser et al., 2000; Sirin \& Park, 2003). When firefly luciferase gene, which does not interfere with HIV-1 production, was inserted into the MFP-inducible lentiviral vectors, substantial levels of infectious vectors could be yielded from the forward and reverse vector systems by co-transfection with packaging plasmid DNAs in HEK293T cells. However, the infectious titer obtained by the forward vector was more than 10 -fold higher than reverse vector, and even in the absence of transactivator and inducer, significant level of the leaky expression of luciferase was observed in the forward vector plasmid transfected-cells, but not in the reverse vector-transfected cells (Shinoda et al., 2009). It can be speculated that the higher background activity in the forward vector was due to the enhancement of gene expression by orientation-dependent cis-acting element such as the woodchuck post-regulatory element (WPRE) and/or the weak promoter activity of the $5^{\prime}$ LTR. Importantly, this tight suppression of inducible unit in the reverse vector was reflected in its ability to produce infectious vectors when a transdominant negative mutant of human VPS4B protein in the VPS pathway, which inhibits budding process of HIV-1, was used as a transgene. Transfection of the reverse vector plasmid containing VPS4B dominantnegative mutant yielded infectious lentiviral vector, transfection of the forward vector could not generate infectious vectors, demonstrating the self-inhibition by the leaky expression of 
VPS4B dominant-negative mutant from the forward vector plasmid in vector producing cells (Shinoda et al., 2009). As expected, subsequent transduction of the transactivatorexpressing cells with the infectious reverse vector bearing the VPS4B mutant resulted in significant inhibition of wild-type HIV-1 production only in the presence of MFP (Shinoda et al., 2009). Thus, this previous study demonstrates that the gene regulatable lentiviral vector system has the capability to transduce anti-HIV gene and subsequently block HIV-1 budding without the problem of self-inhibition during vector production.

\section{Conclusion and future direction}

Lentiviral vectors derived from HIV-1 are attractive gene delivery vehicles in terms of stable and long-term transgene expression in dividing and non-dividing cells. Although strong promoters used to achieve high levels of transgene expression are put into general use in the lentiviral vectors, incorporation of regulatable gene expression system confers transcriptional flexibility to the vector, which expands the potential of the lentiviral vectors for a wide array of gene transfer applications, particularly when undesired side effect would be expected by the constitutive expression of transgene. Nevertheless, many obstacles must be overcome for the clinical application of gene regulatable lentiviral vectors in gene therapy. One of the obstacles is that all the components of a regulatory system should be incorporated into a single vector, limiting the cloning capacity for transgene. Another issue is that there is no gene regulatory system approved by the FDA for clinical use. However, if their safety and efficacy are validated, development of gene regulatable lentiviral vector systems will be a next promising step toward achieving successful gene therapy for otherwise incurable diseases.

\section{Acknowledgment}

We are grateful Wei Xin Chin for proofreading and comments on the manuscript.

\section{References}

Abruzzese, R.V.; Godin, D.; Burcin, M.; Mehta, V.; French, M.; Li, Y.; O'Malley, B.W.; Nordstrom, J.L. (1999). Ligand-dependent regulation of plasmid-based transgene expression in vivo. Hum. Gene Ther., Vol. 10, No. 9, pp. 1499-1507

Anderson, W.F.; Blaese, R.M.; Culver, K. (1990). The ADA human gene therapy clinical protocol: Points to Consider response with clinical protocol, July 6, 1990. Hum. Gene Ther., Vol. 1, No. 3, pp. 331-362

Arhel, N. (2010). Revisiting HIV-1 uncoating. Retrovirology, Vol. 7, pp. 96

Armentano, D.; Sookdeo, C.C.; Hehir, K.M.; Gregory, R.J.; St George, J.A.; Prince, G.A.; Wadsworth, S.C.; Smith, A.E. (1995). Characterization of an adenovirus gene transfer vector containing an E4 deletion. Hum. Gene Ther., Vol. 6, No. 10, pp. 13431353

Armentano, D.; Smith, M.P.; Sookdeo, C.C.; Zabner, J.; Perricone, M.A.; St George, J.A.; Wadsworth, S.C.; Gregory, R.J. (1999). E4ORF3 requirement for achieving longterm transgene expression from the cytomegalovirus promoter in adenovirus vectors. J. Virol., Vol. 73, No. 8, pp. 7031-7034 
Baltimore, D. (1988). Gene therapy. Intracellular immunization. Nature, Vol. 335, No. 6189, pp. 395-396

Banerjea, A.; Li, M.J.; Bauer, G.; Remling, L.; Lee, N.S.; Rossi, J.; Akkina, R. (2003). Inhibition of HIV-1 by lentiviral vector-transduced siRNAs in T lymphocytes differentiated in SCID-hu mice and CD34+ progenitor cell-derived macrophages. Mol. Ther., Vol. 8, No. 1, pp. $62-71$

Baron, U.; Bujard, H. (2000). Tet repressor-based system for regulated gene expression in eukaryotic cells: principles and advances. Methods Enzymol., Vol. 327, pp. 401-421

Basu, V.P.; Song, M.; Gao, L.; Rigby, S.T.; Hanson, M.N.; Bambara, R.A. (2008). Strand transfer events during HIV-1 reverse transcription. Virus Res., Vol. 134, No. 1-2, pp. 19-38

Bergelson, J.M.; Cunningham, J.A.; Droguett, G.; Kurt-Jones, E.A.; Krithivas, A.; Hong, J.S.; Horwitz, M.S.; Crowell, R.L.; Finberg, R.W. (1997). Isolation of a common receptor for Coxsackie B viruses and adenoviruses 2 and 5. Science, Vol. 275, No. 5304, pp. 1320-1323

Berger, E.A.; Murphy, P.M.; Farber, J.M. (1999). Chemokine receptors as HIV-1 coreceptors: roles in viral entry, tropism, and disease. Annu. Rev. Immunol., Vol. 17, pp. 657700

Berk, A.J. (2007). Adenoviridae: The Viruses and Their Replication, In Fields Virology, Knipe, D.M.; Howley, P.M., Vol. 2, pp. 2355, Lippincott Williams \& Wilkins, Philadelphia

Berkhout, B.; Silverman, R.H.; Jeang, K.T. (1989). Tat trans-activates the human immunodeficiency virus through a nascent RNA target. Cell, Vol. 59, No. 2, pp. 273282

Bett, A.J.; Haddara, W.; Prevec, L.; Graham, F.L. (1994). An efficient and flexible system for construction of adenovirus vectors with insertions or deletions in early regions 1 and 3. Proc. Natl. Acad. Sci. USA, Vol. 91, No. 19, pp. 8802-8806

Beutelspacher, S.C.; Ardjomand, N.; Tan, P.H.; Patton, G.S.; Larkin, D.F.; George, A.J.; McClure, M.O. (2005). Comparison of HIV-1 and EIAV-based lentiviral vectors in corneal transduction. Exp. Eye Res., Vol. 80, No. 6, pp. 787-794

Blaese, R.M.; Culver, K.W.; Chang, L.; Anderson, W.F.; Mullen, C.; Nienhuis, A.; Carter, C.; Dunbar, C.; Leitman, S.; Berger, M.; et al. (1993). Treatment of severe combined immunodeficiency disease (SCID) due to adenosine deaminase deficiency with CD34 ${ }^{+}$selected autologous peripheral blood cells transduced with a human ADA gene. Amendment to clinical research project, Project 90-C-195, January 10, 1992. Hum. Gene Ther., Vol. 4, No. 4, pp. 521-527

Blankson, J.N.; Persaud, D.; Siliciano, R.F. (2002). The challenge of viral reservoirs in HIV-1 infection. Annu. Rev. Med., Vol. 53, No. pp. 557-593

Brady, J.; Kashanchi, F. (2005). Tat gets the "green" light on transcription initiation. Retrovirology Vol. 2, pp. 69

Brough, D.E.; Hsu, C.; Kulesa, V.A.; Lee, G.M.; Cantolupo, L.J.; Lizonova, A.; Kovesdi, I. (1997). Activation of transgene expression by early region 4 is responsible for a high level of persistent transgene expression from adenovirus vectors in vivo. J. Virol. Vol. 71, No. 12, pp. 9206-9213

Bukrinskaya, A.; Brichacek, B.; Mann, A.; Stevenson, M. (1998). Establishment of a functional human immunodeficiency virus type 1 (HIV-1) reverse transcription complex involves the cytoskeleton. J. Exp. Med., Vol. 188, No. 11, pp. 2113-2125 
Bukrinsky, M.I.; Sharova, N.; Dempsey, M.P.; Stanwick, T.L.; Bukrinskaya, A.G.; Haggerty, S.; Stevenson, M. (1992). Active nuclear import of human immunodeficiency virus type 1 preintegration complexes. Proc. Natl. Acad. Sci. USA, Vol. 89, No. 14, pp. 6580-6584

Burcin, M.M.; Schiedner, G.; Kochanek, S.; Tsai, S.Y.; O'Malley, B.W. (1999). Adenovirusmediated regulable target gene expression in vivo. Proc. Natl. Acad. Sci. USA, Vol. 96, No. 2, pp. 355-360

Burns, J.C.; Friedmann, T.; Driever, W.; Burrascano, M.; Yee, J.K. (1993). Vesicular stomatitis virus $G$ glycoprotein pseudotyped retroviral vectors: concentration to very high titer and efficient gene transfer into mammalian and nonmammalian cells. Proc. Natl. Acad. Sci. USA, Vol. 90, No. 17, pp. 8033-8037

Charneau, P.; Alizon, M.; Clavel, F. (1992). A second origin of DNA plus-strand synthesis is required for optimal human immunodeficiency virus replication. J. Virol., Vol. 66, No. 5, pp. 2814-2820

Charneau, P.; Mirambeau, G.; Roux, P.; Paulous, S.; Buc, H.; Clavel, F. (1994). HIV-1 reverse transcription. A termination step at the center of the genome. J. Mol. Biol., Vol. 241, No. 5, pp. 651-662

Chen, B.F.; Hsieh, C.L.; Chen, D.S.; Hwang, L.H. (1992). Improved gene expression by a U3based retroviral vector. Biochem. Biophys. Res. Commun., Vol. 184, No. 1, pp. 330-337

Cullen, B.R. (1991). Human immunodeficiency virus as a prototypic complex retrovirus. J. Virol., Vol. 65, No. 3, pp. 1053-1056

Cullen, B.R. (2001). Journey to the center of the cell. Cell, Vol. 105, No. 6, pp. 697-700

Dalgleish, A.G.; Beverley, P.C.; Clapham, P.R.; Crawford, D.H.; Greaves, M.F.; Weiss, R.A. (1984). The CD4 (T4) antigen is an essential component of the receptor for the AIDS retrovirus. Nature, Vol. 312, No. 5996, pp. 763-767

Danthinne, X.; Imperiale, M.J. (2000). Production of first generation adenovirus vectors: a review. Gene Ther., Vol. 7, No. 20, pp. 1707-1714

Dropulic, B.; Hermankova, M.; Pitha, P.M. (1996). A conditionally replicating HIV-1 vector interferes with wild-type HIV-1 replication and spread. Proc. Natl. Acad. Sci. USA, Vol. 93, No. 20, pp. 11103-11108

Dull, T.; Zufferey, R.; Kelly, M.; Mandel, R.J.; Nguyen, M.; Trono, D.; Naldini, L. (1998). A third-generation lentivirus vector with a conditional packaging system. J. Virol., Vol. 72, No. 11, pp. 8463-8471

Engelman, A. (2003). The roles of cellular factors in retroviral integration. Curr. Top. Microbiol. Immunol., Vol. 281, pp. 209-238

Fallaux, F.J.; Kranenburg, O.; Cramer, S.J.; Houweling, A.; Van Ormondt, H.; Hoeben, R.C.; Van Der Eb, A.J. (1996). Characterization of 911: a new helper cell line for the titration and propagation of early region 1-deleted adenoviral vectors. Hum. Gene Ther., Vol. 7, No. 2, pp. 215-222

Fassati, A. (2006). HIV infection of non-dividing cells: a divisive problem. Retrovirology, Vol. 3, pp. 74

Fassati, A.; Goff, S.P. (2001). Characterization of intracellular reverse transcription complexes of human immunodeficiency virus type 1. J. Virol., Vol. 75, No. 8, pp. 3626-3635

Feng, S.; Holland, E.C. (1988), HIV-1 tat trans-activation requires the loop sequence within tar. Nature, Vol. 334, No. 6178, pp. 165-167 
Flint, J.; Shenk, T. (1997). Viral transactivating proteins. Annu. Rev. Genet., Vol. 31, pp. 177212

Flotte, T.R.; Ng, P.; Dylla, D.E.; McCray, P.B., Jr.; Wang, G.; Kolls, J.K.; Hu, J. (2007). Viral vector-mediated and cell-based therapies for treatment of cystic fibrosis. Mol. Ther., Vol. 15, No. 2, pp. 229-241

Forsman, A.; Weiss, R.A. (2008). Why is HIV a pathogen? Trends Microbiol., Vol. 16, No. 12, pp. 555-560

Frankel, A.D.; Young, J.A. (1998). HIV-1: fifteen proteins and an RNA. Annu. Rev. Biochem., Vol. 67, pp. 1-25

Fussenegger, M. (2001). The impact of mammalian gene regulation concepts on functional genomic research, metabolic engineering, and advanced gene therapies. Biotechnol., Prog. Vol. 17, No. 1, pp. 1-51

Galimi, F.; Summers, R.G.; van Praag, H.; Verma, I.M.; Gage, F.H. (2005). A role for bone marrow-derived cells in the vasculature of noninjured CNS. Blood, Vol. 105, No. 6, pp. 2400-2402

Gao, G.P.; Yang, Y.; Wilson, J.M. (1996). Biology of adenovirus vectors with E1 and E4 deletions for liver-directed gene therapy. J. Virol. Vol. 70, No. 12, pp. 8934-8943

Gascon, S.; Paez-Gomez, J.A.; Diaz-Guerra, M.; Scheiffele, P.; Scholl, F.G. (2008). Dualpromoter lentiviral vectors for constitutive and regulated gene expression in neurons. J. Neurosci. Methods, Vol. 168, No. 1, pp. 104-112

Gasmi, M.; Glynn, J.; Jin, M.J.; Jolly, D.J.; Yee, J.K.; Chen, S.T. (1999). Requirements for efficient production and transduction of human immunodeficiency virus type 1based vectors. J. Virol., Vol. 73, No. 3, pp. 1828-1834

Gossen, M.; Bujard, H. (1992). Tight control of gene expression in mammalian cells by tetracycline-responsive promoters. Proc. Natl. Acad. Sci. USA, Vol. 89, No. 12, pp. 5547-5551

Gossen, M.; Freundlieb, S.; Bender, G.; Muller, G.; Hillen, W.; Bujard, H. (1995). Transcriptional activation by tetracyclines in mammalian cells. Science, Vol. 268, No. 5218, pp. 1766-1769

Goverdhana, S.; Puntel, M.; Xiong, W.; Zirger, J.M.; Barcia, C.; Curtin, J.F.; Soffer, E.B.; Mondkar, S.; King, G.D.; Hu, J.; Sciascia, S.A.; Candolfi, M.; Greengold, D.S.; Lowenstein, P.R.; Castro, M.G. (2005). Regulatable gene expression systems for gene therapy applications: progress and future challenges. Mol. Ther., Vol. 12, No. 2, pp. $189-211$

Graham, F.L.; Smiley, J.; Russell, W.C.; Nairn, R. (1977). Characteristics of a human cell line transformed by DNA from human adenovirus type 5. J. Gen. Virol., Vol. 36, No. 1, pp. 59-74

Guild, B.C.; Finer, M.H.; Housman, D.E.; Mulligan, R.C. (1988). Development of retrovirus vectors useful for expressing genes in cultured murine embryonal cells and hematopoietic cells in vivo. J. Virol., Vol. 62, No. 10, pp. 3795-3801

Haack, K.; Cockrell, A.S.; Ma, H.; Israeli, D.; Ho, S.N.; McCown, T.J.; Kafri, T. (2004). Transactivator and structurally optimized inducible lentiviral vectors. Mol. Ther., Vol. 10, No. 3, pp. 585-596

Haraguchi, H.; Sudo, S.; Noda, T.; Momose, F.; Kawaoka, Y.; Morikawa, Y. (2010). Intracellular localization of human immunodeficiency virus type $1 \mathrm{Gag}$ and GagPol 
products and virus particle release: relationship with the Gag-to-GagPol ratio. Microbiol. Immunol., Vol. 54, No. 12, pp. 734-746

Harel, J.; Rassart, E.; Jolicoeur, P. (1981). Cell cycle dependence of synthesis of unintegrated viral DNA in mouse cells newly infected with murine leukemia virus. Virology, Vol. 110, No. 1, pp. 202-207

Hartenbach, S.; Fussenegger, M. (2005). Autoregulated, bidirectional and multicistronic gasinducible mammalian as well as lentiviral expression vectors. J. Biotechnol., Vol. 120, No. 1, pp. 83-98

Hatziioannou, T.; Goff, S.P. (2001). Infection of nondividing cells by Rous sarcoma virus. J. Virol., Vol. 75, No. 19, pp. 9526-9531

Hope, T.J.; Klein, N.P.; Elder, M.E.; Parslow, T.G. (1992). trans-dominant inhibition of human immunodeficiency virus type 1 Rev occurs through formation of inactive protein complexes. J. Virol., Vol. 66, No. 4, pp. 1849-1855

Hurttila, H.; Koponen, J.K.; Kansanen, E.; Jyrkkanen, H.K.; Kivela, A.; Kylatie, R.; YlaHerttuala, S.; Levonen, A.L. (2008). Oxidative stress-inducible lentiviral vectors for gene therapy. Gene Ther., Vol. 15, No. 18, pp. 1271-1279

Imler, J.L.; Chartier, C.; Dreyer, D.; Dieterle, A.; Sainte-Marie, M.; Faure, T.; Pavirani, A.; Mehtali, M. (1996). Novel complementation cell lines derived from human lung carcinoma A549 cells support the growth of E1-deleted adenovirus vectors. Gene Ther., Vol. 3, No. 1, pp. 75-84

Johansen, J.; Rosenblad, C.; Andsberg, K.; Moller, A.; Lundberg, C.; Bjorlund, A.; Johansen, T.E. (2002). Evaluation of Tet-on system to avoid transgene down-regulation in ex vivo gene transfer to the CNS. Gene Ther., Vol. 9, No. 19, pp. 1291-1301

Kafri, T.; van Praag, H.; Gage, F.H.; Verma, I.M. (2000). Lentiviral vectors: regulated gene expression. Mol. Ther., Vol. 1, No. 6, pp. 516-521

Kang, E.M.; De Witte, M.; Malech, H.; Morgan, R.A.; Carter, C.; Leitman, S.F.; Childs, R.; Barrett, A.J.; Little, R.; Tisdale, J.F. (2002). Gene therapy-based treatment for HIVpositive patients with malignancies. J. Hematother. Stem Cell Res., Vol. 11, No. 5, pp. 809-816

Kaul, M.; Garden, G.A.; Lipton, S.A. (2001). Pathways to neuronal injury and apoptosis in HIV-associated dementia. Nature, Vol. 410, No. 6831, pp. 988-994

Kim, S.Y.; Byrn, R.; Groopman, J.; Baltimore, D. (1989). Temporal aspects of DNA and RNA synthesis during human immunodeficiency virus infection: evidence for differential gene expression. J. Virol., Vol. 63, No. 9, pp. 3708-3713

Kim, V.N.; Mitrophanous, K.; Kingsman, S.M.; Kingsman, A.J. (1998). Minimal requirement for a lentivirus vector based on human immunodeficiency virus type 1. J. Virol., Vol. 72, No. 1, pp. 811-816

Kingsman, S.M.; Kingsman, A.J. (1996). The regulation of human immunodeficiency virus type-1 gene expression. Eur. J. Biochem., Vol. 240, No. 3, pp. 491-507

Kitchen, S.G.; Shimizu, S.; An, D.S. (2011). Stem cell-based anti-HIV gene therapy. Virology, Vol. 411, No. 2, pp. 260-272

Klimatcheva, E.; Planelles, V.; Day, S.L.; Fulreader, F.; Renda, M.J.; Rosenblatt, J. (2001). Defective lentiviral vectors are efficiently trafficked by HIV-1 and inhibit its replication. Mol. Ther., Vol. 3, No. 6, pp. 928-939

Kochanek, S.; Clemens, P.R.; Mitani, K.; Chen, H.H.; Chan, S.; Caskey, C.T. (1996). A new adenoviral vector: Replacement of all viral coding sequences with $28 \mathrm{~kb}$ of DNA 
independently expressing both full-length dystrophin and beta-galactosidase. Proc. Natl. Acad. Sci. USA, Vol. 93, No. 12, pp. 5731-5736

Koponen, J.K.; Kankkonen, H.; Kannasto, J.; Wirth, T.; Hillen, W.; Bujard, H.; Yla-Herttuala, S. (2003). Doxycycline-regulated lentiviral vector system with a novel reverse transactivator rtTA2S-M2 shows a tight control of gene expression in vitro and in vivo. Gene Ther., Vol. 10, No. 6, pp. 459-466

Landau, N.R.; Warton, M.; Littman, D.R. (1988). The envelope glycoprotein of the human immunodeficiency virus binds to the immunoglobulin-like domain of CD4. Nature, Vol. 334, No. 6178, pp. 159-162

Leopold, P.L.; Ferris, B.; Grinberg, I.; Worgall, S.; Hackett, N.R.; Crystal, R.G. (1998). Fluorescent virions: dynamic tracking of the pathway of adenoviral gene transfer vectors in living cells. Hum. Gene Ther., Vol. 9, No. 3, pp. 367-378

Levine, F.; Friedmann, T. (1991). Gene therapy techniques. Curr. Opin. Biotechnol., Vol. 2, No. 6, pp. 840-844

Lewinski, M.K.; Bushman, F.D. (2005). Retroviral DNA integration--mechanism and consequences. Adv. Genet., Vol. 55, pp. 147-181

Lewis, P.; Hensel, M.; Emerman, M. (1992). Human immunodeficiency virus infection of cells arrested in the cell cycle. EMBO J., Vol. 11, No. 8, pp. 3053-3058

Lewis, P.; Emerman, M. (1994). Passage through mitosis is required for oncoretroviruses but not for the human immunodeficiency virus. J. Virol., Vol. 68, No. 1, pp. 510-516

Li, M.J.; Bauer, G.; Michienzi, A.; Yee, J.K.; Lee, N.S.; Kim, J.; Li, S.; Castanotto, D.; Zaia, J.; Rossi, J.J. (2003). Inhibition of HIV-1 infection by lentiviral vectors expressing Pol III-promoted anti-HIV RNAs. Mol. Ther., Vol. 8, No. 2, pp. 196-206

Lowenstein, P.R.; Thomas, C.E.; Umana, P.; Gerdes, C.A.; Verakis, T.; Boyer, O.; Tondeur, S.; Klatzmann, D.; Castro, M.G. (2002). High-capacity, helper-dependent, "gutless" adenoviral vectors for gene transfer into brain. Methods Enzymol., Vol. 346, pp. 292311

Ma, Y.; Feigin, A.; Dhawan, V.; Fukuda, M.; Shi, Q.; Greene, P.; Breeze, R.; Fahn, S.; Freed, C.; Eidelberg, D. (2002). Dyskinesia after fetal cell transplantation for parkinsonism: a PET study. Ann. Neurol., Vol. 52, No. 5, pp. 628-634

Malim, M.H.; Bohnlein, S.; Hauber, J.; Cullen, B.R. (1989). Functional dissection of the HIV-1 Rev trans-activator--derivation of a trans-dominant repressor of Rev function. Cell, Vol. 58, No. 1, pp. 205-214

Malim, M.H.; Emerman, M. (2008). HIV-1 accessory proteins--ensuring viral survival in a hostile environment. Cell Host Microbe., Vol. 3, No. 6, pp. 388-398

Mann, R.; Mulligan, R.C.; Baltimore, D. (1983). Construction of a retrovirus packaging mutant and its use to produce helper-free defective retrovirus. Cell, Vol. 33, No. 1, pp. 153-159

Mautino, M.R.; Keiser, N.; Morgan, R.A. (2001). Inhibition of human immunodeficiency virus type 1 (HIV-1) replication by HIV-1-based lentivirus vectors expressing transdominant Rev. J. Virol., Vol. 75, No. 8, pp. 3590-3599

Mautino, M.R.; Morgan, R.A. (2002a). Enhanced inhibition of human immunodeficiency virus type 1 replication by novel lentiviral vectors expressing human immunodeficiency virus type 1 envelope antisense RNA. Hum. Gene Ther., Vol. 13, No. 9, pp. 1027-1037 
Mautino, M.R.; Morgan, R.A. (2002b). Gene therapy of HIV-1 infection using lentiviral vectors expressing anti-HIV-1 genes. AIDS Patient Care STDS, Vol. 16, No. 1, pp. 1126

Mautino, M.R.; Morgan, R.A. (2002c). Inhibition of HIV-1 replication by novel lentiviral vectors expressing transdominant Rev and HIV-1 env antisense. Gene Ther., Vol. 9, No. 7, pp. 421-431

Meadows, D.C.; Gervay-Hague, J. (2006). Current developments in HIV chemotherapy. ChemMedChem, Vol. 1, No. 1, pp. 16-29

Melikyan, G.B. (2008). Common principles and intermediates of viral protein-mediated fusion: the HIV-1 paradigm. Retrovirology, Vol. 5, pp. 111

Miller, A.D.; Rosman, G.J. (1989). Improved retroviral vectors for gene transfer and expression. Biotechniques Vol. 7, No. 9, pp. 980-990

Miller, A.D. (1992a). Human gene therapy comes of age. Nature, Vol. 357, No. 6378, pp. 455460

Miller, A.D. (1992b). Retroviral vectors. Curr. Top. Microbiol. Immunol., Vol. 158, pp. 1-24

Miller, D.G.; Adam, M.A.; Miller, A.D. (1990). Gene transfer by retrovirus vectors occurs only in cells that are actively replicating at the time of infection. Mol. Cell. Biol., Vol. 10, No. 8, pp. 4239-4242

Mitta, B.; Weber, C.C.; Rimann, M.; Fussenegger, M. (2004). Design and in vivo characterization of self-inactivating human and non-human lentiviral expression vectors engineered for streptogramin-adjustable transgene expression. Nucleic Acids Res., Vol. 32, No. 12, pp. e106

Miyake, K.; Suzuki, N.; Matsuoka, H.; Tohyama, T.; Shimada, T. (1998). Stable integration of human immunodeficiency virus-based retroviral vectors into the chromosomes of nondividing cells. Hum. Gene Ther., Vol. 9, No. 4, pp. 467-475

Miyoshi, H.; Blomer, U.; Takahashi, M.; Gage, F.H.; Verma, I.M. (1998). Development of a self-inactivating lentivirus vector. J. Virol., Vol. 72, No. 10, pp. 8150-8157

Miyoshi, H.; Smith, K.A.; Mosier, D.E.; Verma, I.M.; Torbett, B.E. (1999). Transduction of human $\mathrm{CD}^{+} 4^{+}$cells that mediate long-term engraftment of NOD/SCID mice by HIV vectors. Science, Vol. 283, No. 5402, pp. 682-686

Molin, M.; Shoshan, M.C.; Ohman-Forslund, K.; Linder, S.; Akusjarvi, G. (1998). Two novel adenovirus vector systems permitting regulated protein expression in gene transfer experiments. J. Virol., Vol. 72, No. 10, pp. 8358-8361

Mukhtar, M.; Duke, H.; BouHamdan, M.; Pomerantz, R.J. (2000). Anti-human immunodeficiency virus type 1 gene therapy in human central nervous systembased cells: an initial approach against a potential viral reservoir. Hum. Gene Ther., Vol. 11, No. 2, pp. 347-359

Naldini, L.; Blomer, U.; Gallay, P.; Ory, D.; Mulligan, R.; Gage, F.H.; Verma, I.M.; Trono, D. (1996). In vivo gene delivery and stable transduction of nondividing cells by a lentiviral vector. Science, Vol. 272, No. 5259, pp. 263-267

Ng, P.; Beauchamp, C.; Evelegh, C.; Parks, R.; Graham, F.L. (2001). Development of a FLP/frt system for generating helper-dependent adenoviral vectors. Mol. Ther., Vol. 3, No. 5, pp. 809-815

No, D.; Yao, T.P.; Evans, R.M. (1996). Ecdysone-inducible gene expression in mammalian cells and transgenic mice. Proc. Natl. Acad. Sci. USA, Vol. 93, No. 8, pp. 3346-3351 
Nordstrom, J.L. (2003). The antiprogestin-dependent GeneSwitch system for regulated gene therapy. Steroids, Vol. 68, No. 10-13, pp. 1085-1094

Ono, A. (2010), Relationships between plasma membrane microdomains and HIV-1 assembly. Biol. Cell Vol. 102, No. 6, pp. 335-350

Palella, F.J., Jr.; Delaney, K.M.; Moorman, A.C.; Loveless, M.O.; Fuhrer, J.; Satten, G.A.; Aschman, D.J.; Holmberg, S.D. (1998). Declining morbidity and mortality among patients with advanced human immunodeficiency virus infection. HIV Outpatient Study Investigators. N. Engl. J. Med., Vol. 338, No. 13, pp. 853-860

Parker, D.G.; Brereton, H.M.; Klebe, S.; Coster, D.J.; Williams, K.A. (2009). A steroidinducible promoter for the cornea. Br. J. Ophthalmol., Vol. 93, No. 9, pp. 1255-1259

Parks, R.J.; Chen, L.; Anton, M.; Sankar, U.; Rudnicki, M.A.; Graham, F.L. (1996). A helperdependent adenovirus vector system: removal of helper virus by Cre-mediated excision of the viral packaging signal. Proc. Natl. Acad. Sci. USA, Vol. 93, No. 24, pp. 13565-13570

Pluta, K.; Luce, M.J.; Bao, L.; Agha-Mohammadi, S.; Reiser, J. (2005). Tight control of transgene expression by lentivirus vectors containing second-generation tetracycline-responsive promoters. J. Gene Med., Vol. 7, No. 6, pp. 803-817

Podsakoff, G.M.; Engel, B.C.; Carbonaro, D.A.; Choi, C.; Smogorzewska, E.M.; Bauer, G.; Selander, D.; Csik, S.; Wilson, K.; Betts, M.R.; Koup, R.A.; Nabel, G.J.; Bishop, K.; King, S.; Schmidt, M.; von Kalle, C.; Church, J.A.; Kohn, D.B. (2005). Selective survival of peripheral blood lymphocytes in children with HIV-1 following delivery of an anti-HIV gene to bone marrow CD34(+) cells. Mol. Ther., Vol. 12, No. 1, pp. 77-86

Pollard, V.W.; Malim, M.H. (1998). The HIV-1 Rev protein. Annu. Rev. Microbiol., Vol. 52, pp. 491-532

Poluri, A.; van Maanen, M.; Sutton, R.E. (2003). Genetic therapy for HIV/AIDS. Expert Opin. Biol. Ther., Vol. 3, No. 6, pp. 951-963

Purcell, D.F.; Martin, M.A. (1993). Alternative splicing of human immunodeficiency virus type 1 mRNA modulates viral protein expression, replication, and infectivity. $J$. Virol., Vol. 67, No. 11, pp. 6365-6378

Reiser, J.; Lai, Z.; Zhang, X.Y.; Brady, R.O. (2000). Development of multigene and regulated lentivirus vectors. J. Virol., Vol. 74, No. 22, pp. 10589-10599

Richman, D.D. (2001). HIV chemotherapy. Nature, Vol. 410, No. 6831, pp. 995-1001

Robbins, P.D.; Ghivizzani, S.C. (1998). Viral vectors for gene therapy. Pharmacol. Ther., Vol. 80, No. 1, pp. 35-47

Roe, T.; Reynolds, T.C.; Yu, G.; Brown, P.O. (1993). Integration of murine leukemia virus DNA depends on mitosis. EMBO J., Vol. 12, No. 5, pp. 2099-2108

Saez, E.; Nelson, M.C.; Eshelman, B.; Banayo, E.; Koder, A.; Cho, G.J.; Evans, R.M. (2000). Identification of ligands and coligands for the ecdysone-regulated gene switch. Proc. Natl. Acad. Sci. USA, Vol. 97, No. 26, pp. 14512-14517

Schwartz, S.; Felber, B.K.; Benko, D.M.; Fenyo, E.M.; Pavlakis, G.N. (1990). Cloning and functional analysis of multiply spliced mRNA species of human immunodeficiency virus type 1. J. Virol., Vol. 64, No. 6, pp. 2519-2529

Shimotohno, K.; Temin, H.M. (1981). Formation of infectious progeny virus after insertion of herpes simplex thymidine kinase gene into DNA of an avian retrovirus. Cell, Vol. 26, No. 1, pp. 67-77 
Shinoda, Y.; Hieda, K.; Koyanagi, Y.; Suzuki, Y. (2009). Efficient transduction of cytotoxic and anti-HIV-1 genes by a gene-regulatable lentiviral vector. Virus Genes Vol. 39, No. 2. pp. $165-175$

Sirin, O.; Park, F. (2003). Regulating gene expression using self-inactivating lentiviral vectors containing the mifepristone-inducible system. Gene, Vol. 323, pp. 67-77

Somia, N.; Verma, I.M. (2000). Gene therapy: trials and tribulations. Nat. Rev. Genet., Vol. 1, No. 2, pp. 91-99

Stevenson, M. (2003). HIV-1 pathogenesis. Nat. Med., Vol. 9, No. 7, pp. 853-860

Strayer, D.S.; Akkina, R.; Bunnell, B.A.; Dropulic, B.; Planelles, V.; Pomerantz, R.J.; Rossi, J.J.; Zaia, J.A. (2005). Current status of gene therapy strategies to treat HIV/AIDS. Mol. Ther., Vol. 11, No. 6, pp. 823-842

Suzuki, Y.; Craigie, R. (2007). The road to chromatin - nuclear entry of retroviruses. Nat. Rev. Microbiol., Vol. 5, No. 3, pp. 187-196

Szulc, J.; Wiznerowicz, M.; Sauvain, M.O.; Trono, D.; Aebischer, P. (2006). A versatile tool for conditional gene expression and knockdown. Nat. Methods, Vol. 3, No. 2, pp. 109-116

Tabin, C.J.; Hoffmann, J.W.; Goff, S.P.; Weinberg, R.A. (1982). Adaptation of a retrovirus as a eucaryotic vector transmitting the herpes simplex virus thymidine kinase gene. Mol. Cell. Biol., Vol. 2, No. 4, pp. 426-436

Taylor, J.A.; Vojtech, L.; Bahner, I.; Kohn, D.B.; Laer, D.V.; Russell, D.W.; Richard, R.E. (2008). Foamy virus vectors expressing anti-HIV transgenes efficiently block HIV-1 replication. Mol. Ther., Vol. 16, No. 1, pp. 46-51

Tomko, R.P.; Xu, R.; Philipson, L. (1997). HCAR and MCAR: the human and mouse cellular receptors for subgroup $\mathrm{C}$ adenoviruses and group B coxsackieviruses. Proc. Natl. Acad. Sci. USA, Vol. 94, No. 7, pp. 3352-3356

Ulmann, A.; Peyron, R.; Silvestre, L. (1995). Clinical uses of mifepristone (MFP). Ann. N. Y. Acad. Sci., Vol. 761, pp. 248-260

Umana, P.; Gerdes, C.A.; Stone, D.; Davis, J.R.; Ward, D.; Castro, M.G.; Lowenstein, P.R. (2001). Efficient FLPe recombinase enables scalable production of helper-dependent adenoviral vectors with negligible helper-virus contamination. Nat. Biotechnol., Vol. 19, No. 6, pp. 582-585

Verma, I.M.; Weitzman, M.D. (2005). Gene therapy: twenty-first century medicine. Annu. Rev. Biochem., Vol. 74, pp. 711-738

Vigna, E.; Cavalieri, S.; Ailles, L.; Geuna, M.; Loew, R.; Bujard, H.; Naldini, L. (2002), Robust and efficient regulation of transgene expression in vivo by improved tetracyclinedependent lentiviral vectors. Mol. Ther., Vol. 5, No. 3, pp. 252-261

Vogel, R.; Amar, L.; Thi, A.D.; Saillour, P.; Mallet, J. (2004). A single lentivirus vector mediates doxycycline-regulated expression of transgenes in the brain. Hum. Gene Ther., Vol. 15, No. 2, pp. 157-165

Vogt, V.M. (1996). Proteolytic processing and particle maturation. Curr. Top. Microbiol. Immunol., Vol. 214, pp. 95-131

Volberding, P.A.; Deeks, S.G. (2010). Antiretroviral therapy and management of HIV infection. Lancet, Vol. 376, No. 9734, pp. 49-62

Wagner, R.; Graf, M.; Bieler, K.; Wolf, H.; Grunwald, T.; Foley, P.; Uberla, K. (2000). Revindependent expression of synthetic gag-pol genes of human immunodeficiency 
virus type 1 and simian immunodeficiency virus: implications for the safety of lentiviral vectors. Hum. Gene Ther., Vol. 11, No. 17, pp. 2403-2413

Wang, Q.; Jia, X.C.; Finer, M.H. (1995). A packaging cell line for propagation of recombinant adenovirus vectors containing two lethal gene-region deletions. Gene Ther., Vol. 2, No. 10, pp. 775-783

Wang, Y.; O'Malley, B.W., Jr.; Tsai, S.Y.; O'Malley, B.W. (1994). A regulatory system for use in gene transfer. Proc. Natl. Acad. Sci. USA, Vol. 91, No. 17, pp. 8180-8184

Watanabe, S.; Temin, H.M. (1983). Construction of a helper cell line for avian reticuloendotheliosis virus cloning vectors. Mol. Cell. Biol., Vol. 3, No. 12, pp. 22412249

Weber, W.; Fussenegger, M. (2004), Approaches for trigger-inducible viral transgene regulation in gene-based tissue engineering. Curr. Opin. Biotechnol. Vol. 15, No. 5, pp. 383-391

Wei, C.M.; Gibson, M.; Spear, P.G.; Scolnick, E.M. (1981). Construction and isolation of a transmissible retrovirus containing the src gene of Harvey murine sarcoma virus and the thymidine kinase gene of herpes simplex virus type 1. J. Virol., Vol. 39, No. 3, pp. 935-944

Weinberg, J.B.; Matthews, T.J.; Cullen, B.R.; Malim, M.H. (1991). Productive human immunodeficiency virus type 1 (HIV-1) infection of nonproliferating human monocytes. J. Exp. Med., Vol. 174, No. 6, pp. 1477-1482

Whittaker, G.R.; Kann, M.; Helenius, A. (2000). Viral entry into the nucleus. Annu. Rev. Cell Dev. Biol. Vol. 16, pp. 627-651

Wiznerowicz, M.; Trono, D. (2003). Conditional suppression of cellular genes: lentivirus vector-mediated drug-inducible RNA interference. J. Virol., Vol. 77, No. 16, pp. 8957-8961

Wu, X.; Liu, H.; Xiao, H.; Conway, J.A.; Hunter, E.; Kappes, J.C. (1997). Functional RT and IN incorporated into HIV-1 particles independently of the Gag/Pol precursor protein. EMBO J., Vol. 16, No. 16, pp. 5113-5122

Yamashita, M.; Emerman, M. (2006). Retroviral infection of non-dividing cells: old and new perspectives. Virology, Vol. 344, No. 1, pp. 88-93

Yancopoulos, G.D.; Davis, S.; Gale, N.W.; Rudge, J.S.; Wiegand, S.J.; Holash, J. (2000). Vascular-specific growth factors and blood vessel formation. Nature, Vol. 407, No. 6801, pp. 242-248

Yeh, P.; Dedieu, J.F.; Orsini, C.; Vigne, E.; Denefle, P.; Perricaudet, M. (1996). Efficient dual transcomplementation of adenovirus E1 and E4 regions from a 293-derived cell line expressing a minimal E4 functional unit. J. Virol., Vol. 70, No. 1, pp. 559-565

Zufferey, R.; Dull, T.; Mandel, R.J.; Bukovsky, A.; Quiroz, D.; Naldini, L.; Trono, D. (1998). Self-inactivating lentivirus vector for safe and efficient in vivo gene delivery. J. Virol., Vol. 72, No. 12, pp. 9873-9880

Zufferey, R.; Nagy, D.; Mandel, R.J.; Naldini, L.; Trono, D. (1997). Multiply attenuated lentiviral vector achieves efficient gene delivery in vivo. Nat. Biotechnol., Vol. 15, No. 9, pp. 871-875 


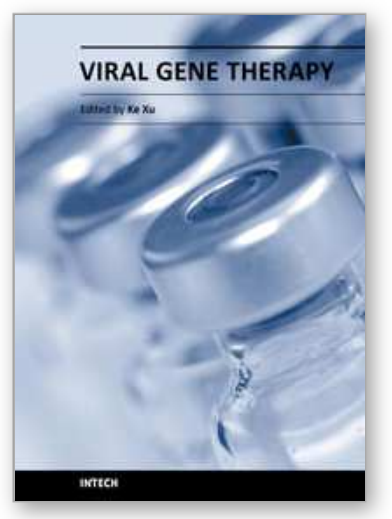

\author{
Viral Gene Therapy \\ Edited by Dr. Ke Xu
}

ISBN 978-953-307-539-6

Hard cover, 450 pages

Publisher InTech

Published online 20, July, 2011

Published in print edition July, 2011

The development of technologies that allow targeting of specific cells has progressed substantially in recent years for several types of vectors, particularly viral vectors, which have been used in $70 \%$ of gene therapy clinical trials. Particular viruses have been selected as gene delivery vehicles because of their capacities to carry foreign genes and their ability to efficiently deliver these genes associated with efficient gene expression. This book is designed to present the most recent advances in viral gene therapy

\title{
How to reference
}

In order to correctly reference this scholarly work, feel free to copy and paste the following:

Yasutsugu Suzuki and Youichi Suzuki (2011). Gene Regulatable Lentiviral Vector System, Viral Gene Therapy, Dr. Ke Xu (Ed.), ISBN: 978-953-307-539-6, InTech, Available from: http://www.intechopen.com/books/viralgene-therapy/gene-regulatable-lentiviral-vector-system

\section{INTECH}

open science | open minds

\author{
InTech Europe \\ University Campus STeP Ri \\ Slavka Krautzeka 83/A \\ 51000 Rijeka, Croatia \\ Phone: +385 (51) 770447 \\ Fax: +385 (51) 686166 \\ www.intechopen.com
}

\author{
InTech China \\ Unit 405, Office Block, Hotel Equatorial Shanghai \\ No.65, Yan An Road (West), Shanghai, 200040, China \\ 中国上海市延安西路65号上海国际贵都大饭店办公楼 405 单元 \\ Phone: +86-21-62489820 \\ Fax: +86-21-62489821
}


(C) 2011 The Author(s). Licensee IntechOpen. This chapter is distributed under the terms of the Creative Commons Attribution-NonCommercialShareAlike-3.0 License, which permits use, distribution and reproduction for non-commercial purposes, provided the original is properly cited and derivative works building on this content are distributed under the same license. 